\title{
Teacher Development Approaches and Strategies in BRAC Nobodhara School
}

\author{
Md Tariqul Islam \\ Lecturer, Institute of Educational Development, BRAC University \\ Dhaka, Bangladesh \\ Email: tariq.ier@gmail.com
}

Doi:10.5296/ ijld.v6i1.8846 URL: http://dx.doi.org/10.5296/ ijld.v6i1.8846

\begin{abstract}
Nobodhara School is a new and unique initiative in the education field of Bangladesh. Different teaching learning and assessment strategies are followed in this school to ensure quality education for the learners. Teachers are the key player to ensure quality of education through their facilitation process in the classroom in any educational institution. In this situation, it was important to know the teacher development approaches of Nobodhara School and its implementation in the teaching learning process. The study aimed to know the educational and professional background the teachers and the followed teacher development policy of Nobodhara School. Moreover, practiced teacher development strategies and the implementation of the professional development by the teachers in the classroom were also explored. Mixed methods approach was followed for data collection and analysis from two branches of Nobodhara School in Dhaka city. Data was collected through interview and questionnaire from Training Coordinator, Subject Mentor and Teachers. Different relevant documents and teacher training schedule were also analyzed for collecting required information. Both qualitative and quantitative data were analyzed simultaneously and presented under different emerged themes. In Nobodhara School, orientation training, subject based training and general professional development trainings are provided to the teachers. Teachers found the trainings very helpful for their professional development. On the other hand, for further development and scaling up of such in-house teacher development system, training duration, facilitation methods and feedback mechanism need to be addressed according to the demand of the teachers.
\end{abstract}

Keywords: In-house training, professional development, School in Bangladesh 


\section{Introduction}

Teachers are the vital actors in any education system to ensure desired educational outcome from the students through their support. Different educational thinkers identified teachers from different perspectives considering their work and responsibility. Dewey acknowledged teachers as an expert for organizing experiences for the students to learn content and social, academic and democratic skills. Whereas, Freire accepted teachers as only one part of the community and described their role as to boost the desire among students to understand and change the world through increasing academic literacy (Singer, Murphy and Hines, 2003). Moreover, irrespective of the type of the schools and location, all teachers in the present time should have some knowledge, skills and attitude related with their profession and responsibility. For example, teachers must know different styles of learning including language, community and cultural context of learning. Similarly, teacher should have expertise to support each student according to their individual needs. Besides, effective teachers should have the skills to construct and manage classroom activities efficiently, communicate with the students effectively, use instructional technology properly and reflect on their practice and to learn from and improve it continually (Darling-Hammond, 2010).

In this situation, qualified teachers are crucial for proper and quality education. Likewise, quality teacher education and continuous demand-driven training is very important to develop the professional excellence of the teachers. However, "the existing teachers' training system of our country is very traditional, insufficient, certificate based, loaded with theoretical knowledge, incomplete in practical learning, based on rote learning and conventional testing system". (Ministry of Education [MoE], p.57)

Teacher development is not a new area in the arena of educational research. In different study, various issues related with teacher development were investigated. For example, teacher demographics, selection, recruitment into teacher education and new teacher induction (Tenore, Dunn, Laughter and Milner, 2010), different problems related with teaching profession and teacher training (Adams and Tulasiewicz, 1995), beginning teachers' professional development strategies (Calderhead and Shorrock, 1997), necessary initiatives in the field of teacher education to support teachers to undertake teaching profession (Darling-Hammond, 2010) were explored following different methodologies and in different contexts.

In Bangladesh, BRAC Nobodhara School is a fee-paying quality education model piloted by the Institute of Educational Development (IED), BRAC University since 2014. The aim of this model is "to increase the quality of mainstream education through emphasising student-centred learning and the holistic development of learners in a way that is sustainable, replicable and scalable" (IED, 2015). Moreover, BRAC Nobodhara School is a unique approach to education in Bangladesh because they not only provide rigorous academic programmes, but also skilful activities that balance an individual's growth in order to achieve a healthy, holistic educational experience. With the aim to inspire positive change in the development of people, several facilities, cultural and activities are made available to the community (BRAC Nobodhara School, 2015). Along with the vision and mission, the key 
features of Nobodhara School (Islam, 2014) are unique in Bangladesh. In this situation, teachers' active and skilled performance can turn these stated vision and mission into reality. Moreover, the Nobodhara School teachers are trained and qualified with ongoing in-service training and they are taught to take active steps in class facilitation (IED, 2015).

After the establishment of Nobodhara School in 2014, several research were done in different aspects of this school. However, there is no research found in the field of teacher development approaches and strategies of the school. In this circumstance, the study aims to explore the academic and professional background, recruitment process of the teachers, underlying theory and approaches for teacher development followed by Nobodhara School and also the implementation and feedback system of the teacher development strategies. From the findings and the recommendation of the study, a clear picture of the teacher development system has been illustrated which will help the Nobodhara School authority to look at the gaps and also the strengths in the teacher development system that need to be addressed to reach the vision and mission of the school. Similarly, other private schools will get a clear idea about the teacher development system in private settings. Moreover, the private schools which have a significant number of teachers or branch, a cluster of schools and even the authority related with government teacher development system can find a way forward for thinking about in-house teacher development system in a different, efficient and effective approach to address the "inadequate, far short of demand and poorly traditional" (Ministry of Education [MoE], p.57) teacher development system.

\section{Understanding teacher development}

Calderhead and Shorrock (1997) in their study presented the conceptual orientations of teacher education from Zeichner (1983) and and Feiman-Nemser (1990). Here, they described five different orientations which refer to a body of values and beliefs about teacher education, these are: academic orientation (subject expertise and quality of own education), practical orientation (artistry and classroom technique), technical orientation (knowledge and behavioral skills associated with teaching competency), personal orientation (interpersonal relationships in the classroom) and critical orientation (schooling as a process of social reform). Besides, Darling-Hammond and Bransford (2005) illustrated a framework for teaching and learning which has implications for teacher education. This framework is organized on three areas of knowledge related with many statements of standards for teaching. Firstly, knowledge of learners and their learning and development process within social contexts. Secondly, understanding of curriculum content and goals, subject matter and skills, student needs and the social purposes of education. Thirdly, understanding of and skills for teaching, including content pedagogical knowledge and knowledge for teaching diverse learners.

Thus, teacher development is a process where different approaches, knowledge, skills and support system are linked according to the need of the teachers and school. In teacher development, different approaches are followed. For instance, pre-service, foundation, in-service, refresher training and engaging teachers in a learning community. Moreover, according to the needs of the teachers, focus of teacher development approach might cover 
learning theory, pedagogy, subject knowledge, class management, assessment and so on. In addition, supervision, monitoring and feedback of teacher performance are designed and implemented in line with different followed approaches and areas of teacher development.

\section{Research Questions}

- Who are the teachers and what is the teacher development policy of Nobodhara School?

- How teachers are being developed in Nobodhara School?

- How the teachers of Nobodhara School implement their learning from different development approaches in classroom teaching learning?

\section{Methodology}

In this study mixed methods approach was followed. To collect qualitative data document analysis and interview were done. Quantitative data was collected through a five-point Likert Scale. Two branches (Uttara and Banasree) of Nobodhara School were selected purposively as research site. Qualitative data were collected from one Training Coordinator, one Subject Mentor and two Teachers from each branch through interview. Total twenty seven Teachers responded through Likert Scale from two branches of Nobodhara School. The story of BRAC Nobodhara School, website of Nobodhara School (http://www.bracnobodhara.net), Teacher Training Schedule 2013, Teachers' Guide (Amar bangle Boi, Class II and Physical Education, Class VII) were analyzed to get relevant information. Qualitative data were transcribed and cleaned methodologically and arranged in different categories according to the research questions of this study. Simple statistical analysis was done through Statistical Package for Social Science (SPSS) to calculate the number of respondents, average and percentage for each item of the Likert Scale. Both qualitative and quantitative data were analyzed simultaneously under different categories emerged from research questions and qualitative data.

\section{Findings}

\subsection{Underlying belief for in-house teacher development initiative}

One of the unique features of BRAC Nobodhara School is 'trained and qualified teachers, with on-going teacher-training' (IED, 2015). To address this unique feature, IED initiated in-house teacher development programme based on the success stories of different short courses, training and research projects since 2004. This issue was describes by the training coordinator of Nobodhara School:

Nobodhara School is one of the major projects of IED. This organization arranges in-house teacher development initiative for several reasons. Firstly, it has experience of designing and delivering training to the government officials and teachers through different training and short courses. Over 600 participants received training from IED on classroom teaching learning and management. Secondly, IED also did several research on teaching learning process and quality education. Most importantly, IED has the scope of hiring experts along with its own professionals for designing and delivering training for Nobodhara School teachers. (Interview, 15.08.2015) 
Form the above data it reveals that, IED has several years of experience of working in the field of educational professional development and based on that experience and availability of human resource this organization initiated in-house ongoing professional development activities for Nobodhara School teachers.

\subsection{Teachers' academic orientation and teacher recruitment policy}

In Nobodhara School, most of the teachers are Master degree holder and few of them have Bachelor degree from different disciplines. Among them $81.5 \%$ have Master degree and $18.5 \%$ teachers have Bachelor degree. Only one teacher has Bachelor and Master Degree in Education where as other teachers do not have any certificate or degree in Education. Among other policies, one of the important policies for teacher recruitment in Nobodhara School is to recruit no experience or less experienced candidates. In teacher recruitment "priority was given to not recruit teachers who have been teaching for long since it may be though to motivate and encourage them to try new things'(IED, 2014). In Nobodhara School, 66.7\% teachers had no teaching experience whereas $11.1 \%$ teachers have three years of teaching experience in other educational institutes. The most experienced teacher in Nobodhara School has thirteen years of teaching experience in other schools and seven months in Nobodhara School. The training coordinator of Nobodhara School described the linkage between teacher development approach of this school and recruiting inexperience teachers:

Inexperience teachers join in teaching with blank head about teaching learning methods and approaches. We can impose different teaching learning methods according to our policy very easily on them. If we recruited experience teachers, we would require to give more time to make them unlearn their previous practices and perceptions to receive our followed teaching methods. (Interview, 15.08.2015)

Similarly, one teacher who had no prior teaching experience told that, 'As I had no teaching experience before joining in Nobodhara School, it was very easy for me to receive the methods of teaching delivered in training. It was very comfortable for me to cope with the vision and mission of this school' (Interview, 08.09.2015). Another teacher mentioned herself as 'clay to receive the teacher development process' (Interview, 08.09.2015). On the other hand one teacher acknowledged her less contribution in the training sessions because of not having experience in teaching (Interview, 10.09.2015). Likewise, one teacher who had six months of teaching experience in other school did not find any significant relationship between experience and receiving teaching learning methods and other issues discussed in the teacher training of Nobodhara School (Interview, 10.09.2015).

Data presented in this section illustrated recruited teachers' appropriate academic qualification for teaching pre-primary to secondary grades. However, followed policy about recruiting fresh graduates viewed differently by the teachers. Some teachers found it very positive for them to receive new teaching learning methods as they need not to unlearn anything. While, others found less scope for them to discuss in the training sessions as they had no experience in the field of teaching. 


\subsection{Teacher development approaches and strategies}

In 2013, Professional Development team was formed in the Institute of Educational Development, BRAC University. The team designed and delivered training to the Nobodhara School teachers (IED, 2014). Teachers' professional development process is implementing following different approaches and strategies. For example, orientation training, subject based training, general professional development training are the main approaches. While, venue and time selection for training, providing teachers' guide, feedback system, demonstration, peer observation and so on are the strategies for supporting the followed approaches. Different issues related with the teacher development approaches and strategies are discussed below in this segment under several sub-categories.

\subsubsection{Orientation training}

Initially the plan was to provide 21 days orientation training to the Nobodhara Teachers. Due to national political instability, this was not possible. So it was narrowed down to a 10-day training programme (IED, 2014). Training coordinator of Nobodhara School describe orientation training as generic training for the teachers to learn teaching style, gesture posture, writing on the board, teaching learning process, interaction with the student, question-answer and so on (Interview, 15.08.2015). Among 27 teachers responded in this study, 18 teachers got orientation training. While fourteen teachers got 10-day training, three teachers got 4-day training and one teacher mentioned that she got 1-day orientation training. According to the Training coordinator, orientation training for newly recruited English Version teachers is 4-day training (Interview, 15.08.2015). Here it is mentionable that Nobodhara School started English Version from 2015. Among the teacher who got orientation training $76.67 \%$ opined that the duration of the training was perfect for them. One teacher who got 10-day training told that "adding more days in the training might be good as it was fundamental training" (Interview, 10.09.2015) another teacher found the orientation training as very important and she enjoyed it very much.

From different opinion and data, it can be said that orientation training was accepted positively by the teachers. All the teachers who are currently working in Nobodhara School did not get this training. Similarly, the duration of the training was not similar for all teachers who got orientation training. Some teachers found the training perfect for them while some recommended for increasing the number of days for orientation training.

\subsubsection{Subject based professional development training}

In Nobodhara School, teachers are getting subject based professional development training on the third Saturday of every month. Holding subject based training once in a month was also supported by $81.48 \%$ teachers of Nobodhara School. During March and April 2014, the training was provided twice a month (first and third Saturday) because of the demand of the teachers (IED, 2014). There is a subject mentor for each subject who facilitates the subject based training to the teachers. Mixed opinion came from the research participants regarding the topic selection for monthly training. According to the training coordinator, "two weeks ago, it is decided which training will go on. Everything depends on the teachers' will" 
(Interview, 15.08.2015). While the subject mentor mentioned that, "mentors select the training content and there is no problem in the content selection process. Teachers also give their opinion and according to their comments some modification are done" (Interview, 01.09.2015). On the other hand, one teacher expressed her view about content selection of subject based training:

It would be better if we asked to propose training content or the problems that need to be addressed in the training earlier. We are informed about the training content on the day before training by the head teacher. As a result we cannot find out the problems that we could discuss in the training. Moreover, this issue can be addressed by selecting the training content in the beginning of an academic year. (Interview, 10.09.2015)

Another teacher raised a different issue:

The training team designs the training schedule where all teachers do not get the training according to their need. Here, some teachers are bound to attend in other's training agenda without any necessity. If the training could be designed according to the need of the teachers, that might be good for all. (Interview, 08.09.2015)

On this matter the training coordinator gave his opinion:

To some extent, subject based trainings are not fruitful. In this regard, we need to bring some teachers to provide training on their subject. Thus, we will be able to make some subject specialist and ensure that other teachers need not to spend time for other subjects. Through this process, all teachers will get their required training. (Interview, 15.08.2015)

For the development of subject based training, mentor mentioned:

Firstly, decision need to be clear regarding job responsibility and communication channel i.e. who do what. Secondly, modes of professional development need to be changed. For example, school visit, class observation, demonstration by the mentor, co-teaching by the mentor and follow-up need to be practiced. (Interview, 01.09.2015)

From the above data, it is clear that there is no fixed system for content selection for the subject based training. The contents or topic for subject based training are selected in different ways. For example, sometimes subject mentor selects the content and informs the teachers through the head teacher one day earlier of the training, occasionally mentor invite the opinion of the teachers for the next training after completion of a monthly training. In this process, some teachers got the training schedule and contents according to their need whilst some teachers need to attend in other teacher training venue. Likewise, communication gap among the decision making authorities exists hampering the subject based teacher development process. In addition, mentor suggested different strategies for improving the mode of subject based professional development.

\subsubsection{General professional development training}

Like subject based training, teachers of Nobodhara School got general professional development training on the third Saturday of every month which is also supported by 
$75.56 \%$ teachers for their effective professional development. About thirty minutes to one hour is allocated on each training day for this training before starting subject based training. In this training, all teachers of Nobodhara School participate. General professional development training focuses on the overall development of the teachers. "Teacher training was provided not only on teaching but also on assessment, report card writing, special child care, child-centred learning and other contemporary and necessary issues that enhance teaching ability in teachers" (IED, 2014, p.11). About the topic selection for general professional development training, it is stated in The story of BRAC Nobodhara School (2014):

Monthly training topics are decided based on the needs of the teachers. For example, in June 2014, the original plan was to provide subject based training, but this was postponed to a later date. Instead, since it was time to provide half-yearly feedback, training was provided on how to grade students, write report cards and provide feedback. This report card was supposed to be in a detailed comment format instead of grades and numbers. (p. 11)

In interview, most of the teachers expressed their positive opinions about different topic of general professional development training. One teacher expressed her view in this way:

To me, ICT (Information and Communication Technology) training seems very important. Many of us can use the learning from this training for our work effectively. (Interview, 10.09.2015)

On the contrary, one teacher pointed out the practice of not reflecting their opinion in the content selection process for general professional development training and the lack of preparation of the trainer:

Maximum contents covered in the general training are very important but we did not get any training on low-cost learning materials. Though we need to develop different types of low-cost learning materials, we are not getting any significant feedback on our work. Similarly, the training that we got on marks distribution was not well explained by the trainer. Most probably, the trainers were not well prepared. (Interview, 10.09.2015)

From the interview and document review, it is clear that the general professional development training is very important and this training is also well accepted by the teachers. Teachers of Nobodhara are getting diverse knowledge and skills related with their profession through this training and they are using the learning in their regular work. However, some important topics like low-cost learning materials are not addressed in the training though teachers need to work on it.

\subsubsection{Teachers' Guide in professional development}

Teachers' Guide (TG) is one of the important initiatives of IED for developing the professional skills and supporting teachers to implement lesson in the class without facing any obstacle according to the curriculum. Teachers' Guide development process and implementation strategies in Nobodhara School are described in The story of BRAC 
Nobodhara School:

Teachers' guides have been prepared to assist teachers in class. IED built the teachers' guide based on the NCTB curriculum and provided relevant workbooks to the students. They built teachers' guides for all subjects and teachers use them for class purposes all the time. Trainers provided training on how to use the subject materials and teachers' guides (IED, 2014, pp.9-10).

The training coordinator gave a detail understanding of the TG developed for Nobodhara School Teachers:

Teachers' Guide is the general guideline for lesson planning which is developed subject wise. Though some sample lesson plans are given in the TG, teachers are free to follow the guideline according to their needs. They have also the scope to discuss the subject mentor and head teacher for planning lesson. (Interview, 15.08.2015)

The above data is also supported by the teachers of Nobodhara School. According to a teacher, "Teachers' Guide helps me identifying learning objectives, teaching learning methods and activities for each lesson very easily. Teachers have the scope to change the number of days and time for any lesson from the proposed teachers' guide" (Interview, 10.09.2015).

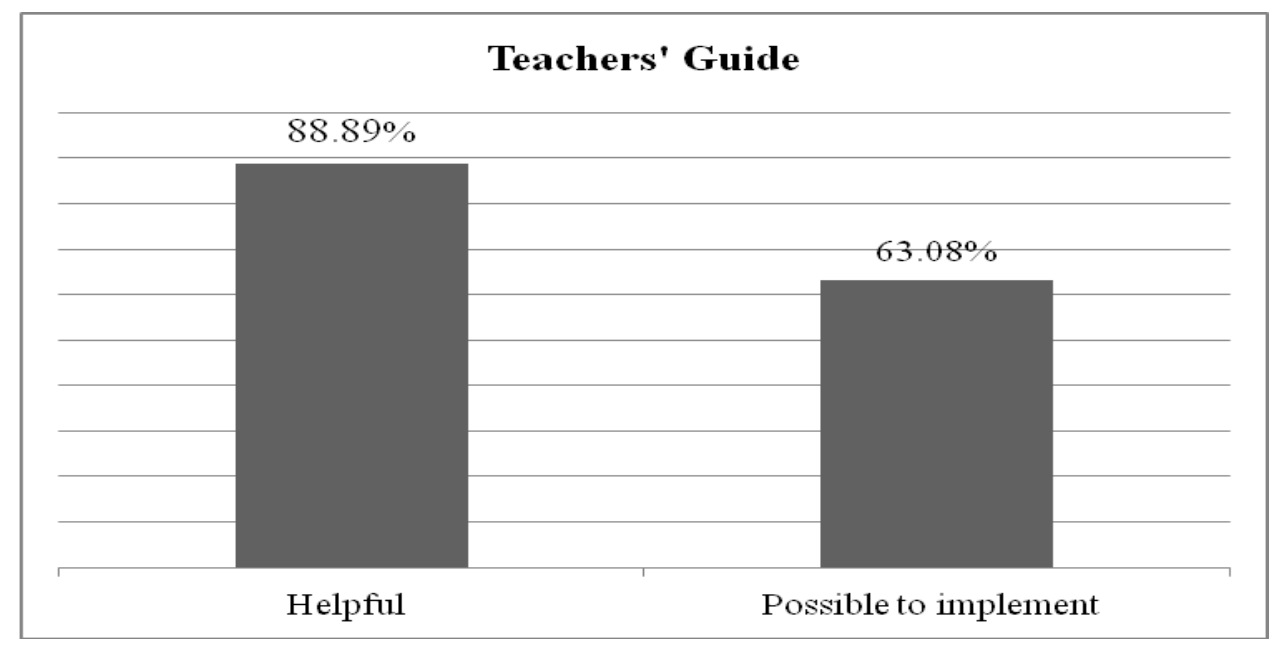

Figure 1. Teachers' perception about TG

According to the figure 1, $88.89 \%$ of the teachers of Nobodhara School found teachers' guide helpful for them to prepare lesson plan and perform class activity. While, $63.08 \%$ of the teachers told that they can conduct their class according to the proposed time in teachers' guide. Teachers who cannot accomplish their lessons according to the suggestion of TG they do it in several days and they also give their notes for the refinement of the next year TG. One teacher mentioned one reason for not being able to implement lesson according to the suggestion of TG:

For different lessons, there are several numbers of alternative activities. For example, poster presentation, power point presentation and role play for a lesson. It is quite 
impossible to implement three activities in a class. (Interview, 08.09.2015)

Another teacher identified the problem in TG development process and gave a suggestion for developing teacher friendly TG:

It would be better if teachers are involved in the TG development process. This is because, at the time of material development, material developers imagine a classroom situation which is much more different from the real classroom. (Interview, 10.09.2015)

The subject mentor pointed out an issue regarding the successful implementation of TG by the teachers in the classroom:

Teachers are facing many challenges for implementing TG successfully in the classroom. Among other challenges, many of them have lack of content knowledge. It is challenging for us to improve the content knowledge through the practiced teacher development system. (Interview, 01.09.2015)

The collected data suggest a different view on TG development and its implementation in the classroom. All the research participants came in a common view that teachers' guide is very helpful for the teachers to implement lesson effectively. However, teachers are facing some problems to implement few lessons according to the TG because of several proposed activities in one lesson. At the same time, teachers mentioned about the flexibility given in the TG to conduct classes according to their situation. On the other hand, teachers suggested for their involvement in the TG development process for meeting the needs of diverse learners in a class.

\subsubsection{Professional learning community}

In Nobodhara School, teachers are also developing their skills from their colleagues in the school compound. In this regard, two major practices were found from the statements of the research participants. Firstly, teachers are demonstrating selected lessons in front of their colleagues and receive feedback from them for their further development. Secondly, teachers observe other teachers' regular class activities and provide feedback to them. In one branch of Nobodhara School between two research sites, teachers are practicing demonstration twice a month. Form that branch, $80 \%$ teachers perceived that practiced demonstration by the teachers helped for their professional development. One teacher expressed her view about the practiced demonstration in the school by the teachers:

Demonstration is obviously necessary for the teachers. The objective of this practice is to develop our skills. Through this process, it is observed that whether we could implement TG properly or not. Moreover, feedback given here are very helpful for my work. (Interview, 10.09.2015)

According to the training coordinator, "demonstration by the teachers is not practicing in both of the branches of Nobodhara School. We are considering second year of Nobodhara School as the year of quality. To address this purpose, school authority arranges demonstration by the teachers on their will" (Interview, 15.08.2015). One teacher from the branch of Nobodhara School where demonstration is practiced told about the arrangement procedure od 
demonstration and also gave suggestions for its improvement:

In our school, head teacher along with other teachers fixes the date for demonstration. To me, it will be better for us if we get feedback after observation of the activities in the real classroom. (Interview, 10.09.2015)

Similarly, in the professional learning community $83.70 \%$ teachers are getting help for their professional development through the practice of observing peers' class activities. One teacher described her involvement in this practice, "from IED we were told to observe others class. For that reason, I observed one class of a teacher (Interview, 10.09.2015). On the other hand, another teacher told in a different way on the same issue:

In this process, one teacher observes another teacher's class. We provide and get feedback for our professional development through this process. . However, we are practicing less than the previous year because of our work load in this year. (Interview, 08.09.2015)

On this issue, a teacher gave her observation in this way:

Sometimes we cannot remember some issues which were discussed in different training. When we observe class activities of other teachers, we can remember those very easily. (Interview, 10.09.2015)

Acknowledging the less peer class observation in the year 2015, one teacher mentioned about the existence of another type of practice by the teacher in the Nobodhara School. According to her:

Last year, we observed significant number of classes of our peers but this year we are not getting enough time for this purpose. Besides, we discussed ourselves on different issues that develop our professional skills. For example, I learnt from my colleagues how to handle hyper active students. (Interview, 08.09.2015)

From the above data, it is visible that teachers in Nobodhara School are in such a professional community where they are getting some mentionable opportunities for their professional development. However, the practice is not similar in the existing two branches and practices of learning from the peer in 2015 are not like 2014 as well.

\subsubsection{Feedback system in professional development}

Teachers in Nobodhara School are getting feedback on their teaching in the classroom from IED staff, subject mentor, head teacher and campus manager. According to $90.37 \%$ teachers, received feedback from the mentioned professionals is very helpful for their professional development. Regarding feedback system for the teaching learning in Nobodhara School, training coordinator mentioned:

We do not practice 'sudden visit' system. We inform teachers earlier, seek their permission and visit their class. We give feedback to the teachers for their future development. (Interview, 15.08.2015) 
On the other hand, one teacher mentioned about the practice of 'sudden visit' in Nobodhara School differently. However, she also acknowledges the importance of class observation and providing feedback by different professionals. According to her,

Class observation is done both with and without taking prior permission to the teachers. If someone comes to the class without any notice on a day of class test, s/he cannot observe teaching learning practice in the classroom. However, the feedback is important for the improvement of my activities. For instance, I requested students to give their writings in a paper from their note book in my class. But the observer's feedback was to provide extra papers to the students not getting paper from their note book. (Interview, 10.09.2015)

One teacher told about the professionals who observe class frequently and the types of the feedback given by them:

Head teacher and the campus manager observe classes more than others. They give feedback very positively. Such as, you did this very well and if you do this in this manner that will be excellent. (Interview, 08.09.2015)

Another teacher told about the practice of the class observation and giving feedback in two academic years and focus of subject mentors in the feedback giving process:

In the last year, class activities were observed more than this academic year. Different observers observe class from different aspect. For example, subject mentors check whether we followed the TG exactly or not. Sometime it is not possible to implement TG exactly in the real classroom. However, we received all of their given feedback very positively. (Interview, 10.09.2015)

Likewise, another teacher mentioned about the lower frequency of class observation in the year 2015 than the last year. She also mentioned about the importance of the feedback given by the mentors and its necessity for their professional development. According to her,

Last year, feedback given by the mentors was very effective. This year, they are observing fewer classes than the previous year. Their class observation and giving feedback can support teachers for their professional development. For this reason, we expect them in our class for more class observation, minimum three class observation in an academic year for a subject. (Interview, 08.09.15)

Subject mentor also told that the class observation and feedback giving system is not practicing in 2015 like last academic year. Here, he pointed out that the role of the mentor is not clear to him.

After analyzing the data of this section, it is found that for the professional development of the teachers of Nobodhara School observing class activities and providing positive feedback by different professionals are very essential. Most of the teachers accepted the role of this system for their professional enhancement and expect its continuation as well. However, class observation system and role in this regard is not clear to all professionals related with Nobodhara School. 


\subsection{Knowledge for teaching covered in the teacher development process}

In orientation and general professional development training, teachers were trained on different content areas related with teaching profession. The training coordinator mentioned that,

Orientation training is the generic training for the teachers. Here, they learnt about the style of teaching, gesture-posture, system of writing on the board, teaching learning process, methods of interaction with the students, question-answer techniques and so on. Whereas, General Professional Development Training is designed for providing need based training to the teachers (Interview, 15.08.2015).

In the orientation training different types of content were addressed. Such as, mission, vision and objectives of Nobodhara School, journal writing and reflective writing, ICT for teachers, teaching learning strategies: teachers vs. child centered teaching learning strategies, different types of leaching learning strategies, block teaching, group teaching, use of task board, basic concepts and characteristics of learning styles, social and emotional learning, summative and formative assessment, portfolio, record keeping and reporting, feedback and feed forward, teacher's prompt, lesson planning, mentoring and appraisal system, school management and analytical thinking (Training Schedule of Nobodhara School, 2013).

Moreover, training on different subjects was given for the subject teachers in different sessions in the orientation training. Besides, different contents were covered in the general professional development training. For example, ICT, test paper development, marks distribution, science fair arrangement, special need children, lesson planning, classroom management, annual production and so on.

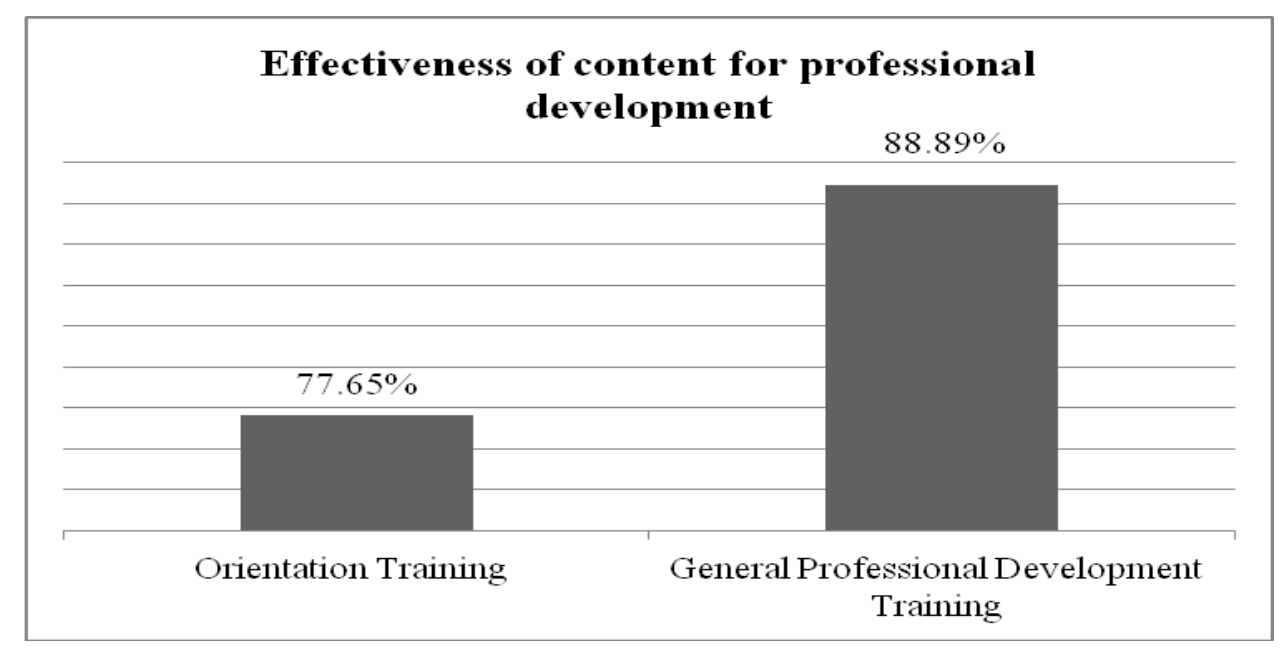

Figure 2. Teachers' perception about content's effectiveness of different trainings

In the figure 2 , it is observed that $77.65 \%$ teachers found the contents of orientation training were effective for their professional development. Whereas, $88.89 \%$ teachers opined that the contents of general professional development training were effective for their professional development. 


\subsection{Methods of training: practical and technical orientation}

Different types of training methods were followed for different approaches of training in Nobodhara School. In the figure 3, it is clear that teacher showed their positive opinion regarding the methods followed in different approaches of training.

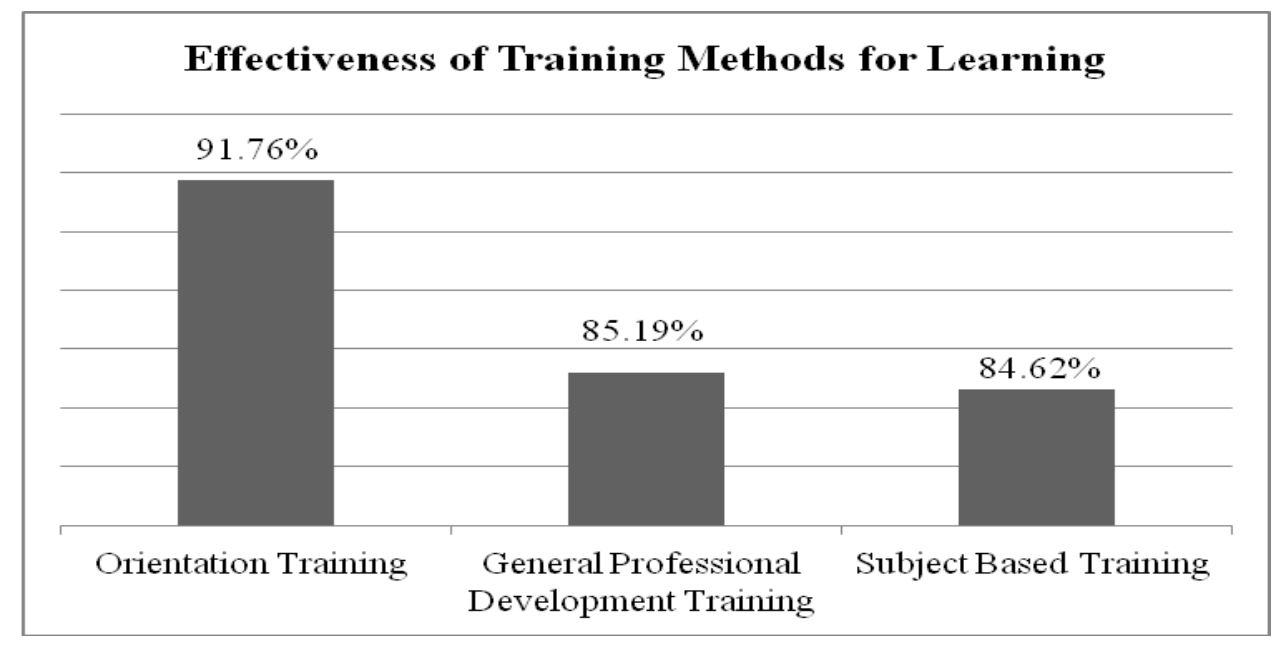

Figure 3. Teachers' perception about effectiveness of training methods for their learning

To the teachers, followed training methods in orientation training were most effective for them to learn. Whereas, subject based training methods are comparatively less effective for their learning. In the orientation and general professional development training, teachers got a variety of practical and technical orientation which is very helpful for their professional practice. Such as, PPT presentation, discussion, assignment, group work, individual presentation, demonstration, games, role play, idea sharing, participatory approach, activity based, lecture and so on. In the subject based training, mentor sit with the subject teachers and discuss on different problems faced by the teachers. To some extent, small demonstration took place in this training. One teacher expressed her opinion regarding subject based training in this way, "it seems to me as a discussion not training" (Interview, 10.09.2015). However, one teacher told that "the way in which subject based training is conducting is perfect for my learning" (Interview, 08.09.2015).

\subsection{Implementation of received training}

Teachers in Nobodhara School, showed a very positive perception regarding the implementation of their received training in their professional activities. In table 1 , it is visible that $88.24 \%$ teachers perceived that they can use their learning from the orientation training for their professional need. Similarly, $81.48 \%$ and $77.78 \%$ teachers opined that they are implementing their learning in school received from subject based and General Professional Development training respectively. 
Table 1. Teachers' perception about the implementation of received training in profession

\begin{tabular}{|lr|}
\hline Training & Percentage \\
\hline Orientation & 88.24 \\
\hline General Professional Development & 77.78 \\
\hline Subject Based & 81.48 \\
\hline
\end{tabular}

Similar data also found from the interview of the teachers. One of the teachers gave example of her learning and implementation of them in her profession:

In orientation training, I have learnt classroom management, making ground rules, arranging group work and so on. Now, I can implement them in my classroom according to my need. (Interview, 10.09.2015)

The teachers also mentioned some limitations for implementing subject based training according to the instruction given in the training sessions. Here, she mentioned that "to some extent we cannot implement the training in the real classroom because of the limitations of teaching learning materials. For example, picture, video, multimedia projector, electricity, science equipments etc" (Interview, 10.09.2015).

From the collected data, it is visible that teachers are using maximum of their learning from different trainings in their professional purposes. They also mentioned some limitations in the available facilities for implementing learning from different types of training.

\section{Recommendations and conclusion}

Orientation training needs to be provided to all teachers. Before the beginning of an academic year orientation training can be arranged for newly recruited teachers where the scope of participation of all teachers needs to be ensured. This orientation training will be considered refresher training for the teachers who got it in the previous year/s.

In the topic selection process for subject based training, teachers need to be engaged. It can be ensured by selecting the probable topics one or two months earlier for an academic year before starting that year. When new topic or issues come then it should be ensured that teachers are concern about the next training topic at least one week earlier.

To get the effective results from subject based training, role of mentors need to be clearly defined. Similarly, the interaction between mentor and teachers need to be increased following different strategies. Such as, school visit, class observation, demonstration and co-teaching by the mentor and follow-up session.

Some issues that teachers need to practice in their profession like 'using low-cost or no-cost learning materials in the classroom' should be provided training earlier. For this reason, professional development team of IED need to engage teachers for selecting training for the upcoming months for general professional development trainings.

As the teachers' guides are very helpful for the teachers for designing their lesson plan implementing lessons in the classroom, IED should continue to develop TG for all subjects. 
Similarly, to address the needs of the real classroom, teachers need to be engaged in the TG development process. Here, some workshops can be arranged by IED where teacher will participate and learn the process of TG development. After that, teacher will develop their own TG and submit to IED team for its finalization and approval.

Practices of professional learning community should be continued in all branches of Nobodhara School. As the teachers found demonstration and classroom observation by the peers are very helpful, teachers should get the opportunity according to their needs.

Different professionals from IED and Nobodhara School observe teaching learning practices of the teachers. Most of the teachers took the system of observation and providing feedback very positively. In this situation, the role of different professionals related with Nobodhara School need to be clearly defined and circulated among all professionals. As a result, confusion among different stakeholders will be removed and teachers will get their required professional development support.

Different types of training are supporting teachers in Nobodhara School to enhance their knowledge and skills in a standard level. To get the maximum results of their learning teaching learning and other materials e.g. picture, video, multimedia projector, electricity, science equipments and so on need to be ensured for the teachers.

Finally, as IED has experience and expertise in the field of teacher development, this organization can arrange or offer training to the teachers of different schools after addressing different issues of its teacher development system. Similarly, schools which have experienced teachers can organize in-house orientation and professional development trainings for their own and teachers from other schools as well.

\section{References}

Adams, A. and Tulasiewicz, W. (1995). The Crisis in Teacher Education: A European Concern? London: The Falmer Press.

Calderhead, J. and Shorrock, S. B. (1997).Understanding Teacher Education: Case Studies in the Professional Development of Beginning Teachers. London: The Falmer Press.

Darling-Hammond, L., \& Bransford, J. (with LePage, P., Hammerness, K., \& Duffy, H.). (2005). Preparing teachers for a changing world: What teachers should learn and be able to do. San Francisco: Jossey-Bass.

Darling-Hammond. L. (2010). Constructing 21st-century teacher education. In Hill-Jackson, V. and Lewis, C. (eds.) Transforming teacher education: What went wrong with teacher training, and how we can fix it. Virginia: Stylus Publishing, LLC.

Institute of Educational Development [IED].(2015). BRAC Nobodhara School. Retrieved from http://iedbracu.ac.bd/?page_id=104

Institute of Educational Development [IED]. (2014). The story of BRAC Nobodhara School. 
BRAC University.

Islam, S. F. S. (2014). Low-Cost School with Quality: Can BRAC's Nabodhara Pilot Set a Trend? Bangladesh Education Journal. 29-37.

Ministry of Education. (2010). National Education Policy. Government of the People's Republic of Bangladesh. Dhaka.

Singer, A. J., Murphy, M. and Hines, S. M. (2003). Teaching to learn, learning to teach: A handbook for secondary school teacher. Lawrence Erlbaum Associates, Publishers.

Tenore, F. B., Dunn, A. C., Laughter, J. C., and Milner. H. R. (2010). Teacher candidate selection, recruitment, and induction: A critical analysis with implications for transformation. In Hill-Jackson, V. and Lewis, C. (eds.) Transforming teacher education: What went wrong with teacher training, and how we can fix it. Virginia: Stylus Publishing, LLC. 